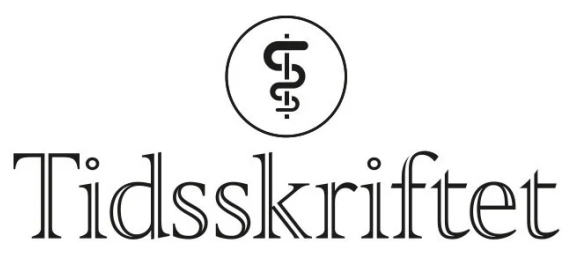

DEN NORSKE LEGEFORENING

\title{
En problematisk helt
}

ANMELDELSER

\section{OLE DIDRIK LAERUM}

Finsenlaboratoriet

Rigshospitalet/Københavns Universitet

Vogt, Carl Emil

Fridtjof Nansen

Mannen og verden. 564 s, ill. Oslo: Cappelen Damm, 2011. Pris NOK 399

ISBN 978-82-02-30665-6

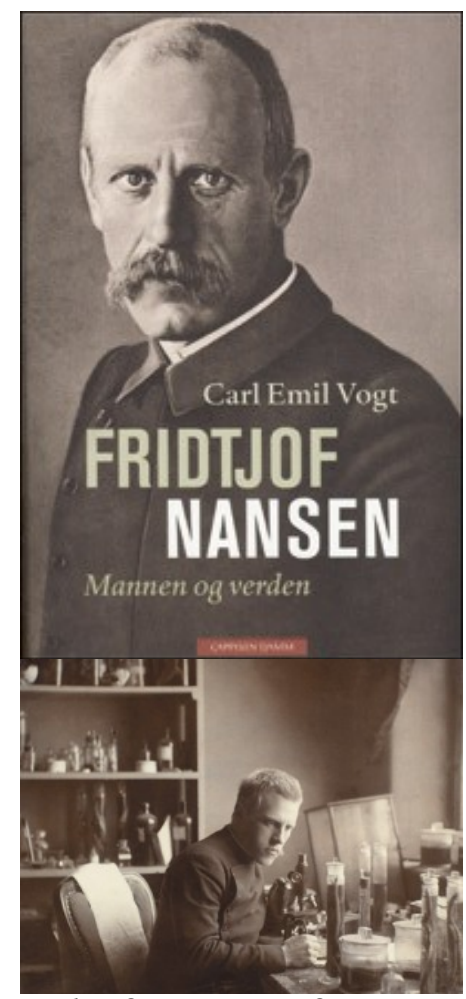

Fridtjof Nansen var først og

fremst forsker. Her er han i

sitt laboratorium ved Bergens 
Museum. Foto Johan v. d. Fehr

og Universitetsbiblioteket i

Bergen

Den første biografien om Fridtjof Nansen (1861-1930) kom ut i 1896. Da skipet Fram med Nansen i spissen kom tilbake til Kristiania etter en tre års ekspedisjon i Nordishavet, lå biografien klar for salg. Da hadde han og Hjalmar Johansen (1867-1913) nådd nesten frem til Nordpolen. Allerede i 1889, da han og medarbeidere hadde gått over Grønland, ble det en feiring nesten uten grenser, og den 28 år gamle Nansen ble gjenstand for en enorm beundring. Ved hjemkomsten sju år seinere ble han verdensberømt.

Men polarferdene var bare en del av Fridtjof Nansens mange triumfer gjennom livet. Ettertiden har hatt problemer med å forholde seg til ham, for det går nesten ikke an for ett eneste menneske å ha så mange ulike talenter som utfolder seg på topp nivå. Han var fysisk sterk, en glimrende skiløper og sprengte grenser gjennom polarekspedisjonene sine. Dertil var han språkmektig og skrev flere bøker som ble bestselgere og gitt ut på en rekke språk. Han var dessuten en dyktig tegner, men aller mest var han forsker. Ekspedisjonene var ikke bare for å oppdage nytt land, men like mye for å utforske områdene de kom til.

\section{Allsidig zoolog}

I helsefaglig sammenheng har livshistorien til Fridtjof Nansen stor interesse. Han begynte karrieren med å studere zoologi ved Det Kongelige Frederiks Universitet i Kristiania i 1881 og tok i tillegg forberedende prøver i latin og medisin. Alt året etter ble han med en selfangstskute til Nordishavet for å undersøke dyrelivet i regi av Universitetets zoologiske samlinger. Etter fem måneder underveis hadde han lært seg mye om sjømannslivet, og en livslang interesse for Arktis var vekket.

Som nyutdannet zoolog kom han i 1882 til Bergen for å arbeide ved Bergens Museum. Her utførte han på tre år et doktorarbeid om utviklingen av nervesystemet hos slimålen, og han var en av de aller første som påviste nevronets betydning. Det skjedde under kyndig veiledning av de to biologiinteresserte medisinerne og lepraforskerne Daniel C. Danielssen (1815-94) og Gerhard Armauer Hansen (1841-1912).

En nær venn av Nansen var legen Sophus Torup (1861-1937). Han var opprinnelig fra Odense, men kom i 1889 til Norge som vår første professor i fysiologi. På samme måte som de to nevnte Bergens-legene var Torup også interessert i marinbiologi, og han var en av grunnleggerne av Biologisk stasjon i Drøbak. I Torup hadde Nansen en dyktig rådgiver i ernæringsspørsmål når han planla ekspedisjonene sine. Nansen fikk først et professorat i zoologi ved Universitetet i Oslo, men siden ble det forandret til oseanografi. Han hadde alltid en solid forankring i vitenskap, selv om livet førte med seg mange andre oppgaver.

\section{Humanist og fredselsker}

I den andre halvdelen av livet ble Fridtjof Nansen mer og mer opptatt av humanitært arbeid. I egenskap av leder for en internasjonal humanitær organisasjon gjorde han en stor innsats for å redde flere hundretusener av russere fra sultedøden. Han drev også med fredsarbeid i regi av Folkeforbundet og var den første høykommissæren for flyktninger. Han bidro også til å repatriere krigsfanger etter første verdenskrig.

Som norsk politiker var Nansen omstridt, men like fullt var han helt instrumentell for å sikre Norge internasjonal støtte da vi ble uavhengige i 1905. Det var også han som overtalte den danske prins Carl og hans kone prinsesse Maud til å bli kongepar i Norge. Dronning Maud og kong Haakon ble hans nære venner for livstid, og ikke minst lærte han dem å gå på ski. 
10. oktober 2011 var det 150 år siden Fridtjof Nansen ble født, og i den anledning er det blitt gitt ut flere bøker om ham. Blant annet har Harald Dag Jølle gitt ut en fyldig biografi om oppdageren Nansen, Det norske Videnskaps-Akademi har gitt ut en samling med utvalgte artikler om Nansen, basert på de årlige minneforelesningene på fødselsdagen hans, og i tillegg er det blitt gitt ut en bok om hans siste store kjærlighetsaffære. For Nansen hadde også stor sans for kvinner.

\section{Nødvendig med nok en biografi?}

Samler man absolutt alt som er skrevet om Fridtjof Nansen gjennom tidene, vil det fylle atskillige hyllemetere. Trenger vi så flere biografier om ham: Er ikke absolutt alt kjent fra før om denne allsidige forskeren, polarhelten og humanisten?

Carl Emil Vogt er en av våre yngre historikere og faglitterære forfattere. Han har tidligere skrevet doktoravhandling om Nansens humanitære arbeid og også gitt ut en bok med tittelen Nansens kamp. Under tittelen Mannen og verden har han skrevet foreliggende omfattende biografi. Den følger Nansen fra fødsel til død, både med hans faglige virke og privatliv. Med bakgrunn i omfattende kildestudier kaster han nytt lys over Nansen som internasjonal politiker og hans humanitære arbeid. På en overbevisende måte forteller Vogt om hvordan den berømte polarhelt, zoolog og siden professor i oseanografi utvikler seg til en humanist av klasse. Hans våkne samvittighet ble sterkere med årene, og når han hørte om hungersnød og flyktningers miserable liv i andre land, kunne han ikke la være å gjøre noe. Og Nansen ble hørt på. Ikke nok med det, men hans internasjonale renommé var så stort at det i seg selv åpnet mange stengte dører, og navnet hans kunne brukes som symbol. På den måten står han fortsatt som en inspirator, og minnet hans har ikke falmet med årene.

\section{Et vanskelig sinn}

Forfatteren legger ikke skjul på at Nansen hadde et vanskelig sinn. Han hadde store humørsvingninger og særlig vanskelig for å åpne seg for sine nærmeste. Familien var splittet, og kontakten med barna ble høyst variabel. Et ekstremt arbeidspress og mye reising med langvarige utenlandsopphold gjorde ikke saken lettere. Dette kommer særlig sterkt frem mot slutten av boken. Vogt siterer først nobelprisvinneren Carl von Ossietzky (1889-1938) som skrev følgende om Nansen:

«Den som en gang har hørt ham tale, kommer aldri til å glemme denne høie, ridderlige skikkelsen, aldri den høflige klang i hans stemme. Menneskevennen Fridtjof Nansen var hverken svak eller sentimental eller fanatiker. Han hadde ikke bare et godt hjerte, men en stor forstand. Det var hemmeligheten ved hans hell. Det var forskjellen på ham og de mange virkningsløse menneskevenner som så gjerne vil omfavne verden, men nærer motvilje mot forstanden.»

Men så legger Vogt til for egen regning: «Fridtjof Nansen nådde tidlig i livet en type berømmelse som ikke bare er sunn. Han ble gjenstand for en voldsom heltedyrkelse. Han fikk et oppblåst selvbilde og fremsto slett ikke utelukkende som sympatisk. Kone og barn fikk lide for den selvopptatte, ekstremt ambisiøse, rastløse og arbeidsnarkomane mannens nykker. Lykkelig var han kun i perioder.»

Den foreliggende biografien er godt skrevet og har et relativt fyldig bildemateriale, til dels fotografert av Nansen selv. Med et så enormt materiale til rådighet er det ikke underlig at boken blir omfattende. Enkelte steder blir den vel detaljrik, og den logiske oppbyggingen av livshistorien er ikke alltid like vellykket. Men den er drivende spennende og kaster mange lysstråler inn over mer eller mindre ukjente deler av livet til en av de mest berømte, allsidige og merkelige livsskjebnene i norsk historie. 
Jeg anbefaler boken til alle med interesse for norsk historie og, ikke minst, grunnlaget for moderne humanitært arbeid. For dem som hovedsakelig er interessert i medisin, er det også en del å finne, særlig om hans samarbeid med flere medisinske forskere.

Dessuten kan noen hver ha utbytte av å lese om hvordan det er å tilhøre nærmeste familie til en som har heltestatus. Det er ikke uproblematisk. At boken er tykk skal ikke skremme leseren. Man blir fort revet med, og jeg kan trygt anbefale biografien.

Publisert: 13. desember 2011. Tidsskr Nor Legeforen. DOI: 10.4045/tidsskr.11.1386

(C) Tidsskrift for Den norske legeforening 2023. Lastet ned fra tidsskriftet.no 26. april 2023. 